\title{
Quinoa in pre-Hispanic central Chile: contributions from archaeology and cultural processes.
}

\author{
María Teresa Planella Ortíz ${ }^{1,2 .}$ \\ ${ }^{1}$ Universidad de Chile. \\ ${ }^{2}$ Sociedad Chilena de Arqueología. Santiago, Chile.
}

\begin{abstract}
M.T. Planella. 2019. Quinoa in pre-Hispanic central Chile: contributions from archaeology and cultural processes. Cien. Inv. Agr. 46(2): 69-81. This paper provides findings from archaeological, archaeobotanical, ethnographic and morphometric investigations regarding the ancient presence of Chenopodium and the use of quinoa (Chenopodium quinoa Willd.) in central Chile from before the Christian era up to the present times, and discusses the importance of this crop for the economic and social development of the various pre-Hispanic indigenous cultural groups who inhabited the different areas and ecosystems of the region. This background knowledge allows us to assess the beginning and unfolding of this crop's long history, which shows how quinoa accompanied our predecessors, their descendants and the groups resulting from Hispanic-indigenous interbreeding in this territory, and how its cultivation and use remain current in different social events inside rural communities in Chile today.
\end{abstract}

Keywords: Central Chile, cultural groups, quinoa.

\section{Introduction}

The cultural processes occurring in central Chile have had a long and significant history. Our study draws on many socioeconomic milestones and material expressions that are rich and important for understanding our indigenous peoples and their legacies, many of which still persist today. One of these is the ability to recognize the potential resources in nature that have been gradually incorporated over time as foodstuffs and that have influenced and modified the basic sustenance and social order of pre-Hispanic social groups. Quinoa rightly represents one of the vegetal resources

Received Mar 23, 2019. Accepted Jun 04, 2019 Corresponding author: mtplanella@gmail.com that has led our main current focus, because of its early use in gathering processes and prolonged initial stages of human manipulation prior to the introduction of maize (Zea mays L.) and beans (Phaseolus sp.) in central Chile, which have no known local wild ancestors.

The objective of this article is to report and highlight, through a retrospective study of archaeological and chronological information, how the presence of Chenopodium in nature, first through its availability for the hunter-gatherer groups who inhabited central Chilean territory and then through the presence of its seeds among the cultigens and wild flora record from the settlements of various ceramic-using local groups, up to the time of the contact with the Inka and Hispanic invasions 
affected the local groups' way of life, and their options for incorporating new possibilities and varied products into their daily subsistence; and also how Chenopodium quinoa became a part of their social gatherings and other events with ritual connotations. Besides, the survival and continued use of quinoa in actual rural communities of central Chile is remarkable. These communities, year after year, revive the syncretic conditions that arise from sowing and harvesting, the use of both ancestral and modern tools, the systems of exchange, such as barter and trading, and the specific religious and social ceremonials that identifies each location and whose origins go back hundred of years in the past.

\section{Materials and Methods}

Previously published information was used, principally the 2018 'Boletín del Museo Nacional de Historia Natural' 67(1): 113-142, “Tiempo, cultura y significado en los modos de uso de Chenopodium quinoa" [Time, culture and meaning in the uses of Chenopodium quinoa], by M. Teresa Planella, Victoria Castro, Alejandra Vidal and M. Blanca Tagle, an extract of which refers to central Chile.

To obtain evidence of quinoa at the sites mentioned in this article, we used the flotation method on sediments extracted from sample columns and selected sectors of specific interest (hearths, middens, stores); the macroremains recovered were then analyzed and identified. Furthermore, multiple analyses of residues adhering to the sides and other parts of ceramic pots, bedrock mortars, etc. (microremains) were performed, prioritizing the recovery of the full set of microfossils (Coil et al., 2003).

\section{Pre-Hispanic data on quinoa in central Chile}

Central Chile is considered the territory extending from the Choapa River in the north ( $\left.31^{\circ} 50^{\prime} \mathrm{S}\right)$ to the Maule River in the south ( $\left.35^{\circ} 40^{\prime} \mathrm{S}\right)$. Records from different paleoecological systems indicate that this territory has been populated for the last 12,000-13,000 years. Archaeological investigations, together with paleoclimatic, geomorphological, pollen, paleofauna and archaeobotanical studies, have made it possible to determine the coexistence of human groups with extinct species of fauna, especially herbivores, from the end of the Pleistocene (Núñez et al., 1994; Jackson et al., 2007) and with plant species from different local environments that show signs of human activity (Heusser, 1990; Gajardo, 1994; Valero-Garcés et al., 2005; Maldonado, 2007; Planella and McRostie, 2008; Maldonado, 2010). The presence of Chenopodiaceae in plant contexts deposited during warm, dry climatic episodes is also evident in sediment samples from pollen columns in strata from the early, middle and late Holocene, dating from 11,000-9000 years BP onwards (Heusser, 1983; Villagrán and Varela, 1990; Rojas, 1991; Villa-Martínez et al., 2003; Maldonado and Villagrán, 2002, 2006). Climate fluctuations allowed the development of Chenopodiaceae-Amaranthaceae; this finding suggests that they were available in the herbaceous flora for gathering by human groups in the region. One example of this is the high proportion of halophytes in pollen samples from the Nague site $\left(32^{\circ} \mathrm{S}\right)$. Together with the first development phase of the forest in this part of the semiarid north (4400-1800 years BP), this result coincides with the period of more permanent human settlements in the area (Maldonado and Villagrán, 2002).

Hunter-gatherer groups from 3000 to $300 \mathrm{BC}$ can also be linked to the use of Chenopodiaceae in more ways than gathering from the natural environment. Evidence of this has been recovered through archaeobotanical work with the finding of a set of carbonized seeds of the genus Chenopodium with morphological attributes indicating incipient human intervention, in the middens and hearths of two sites in the Andes Mountain Range. The sites, at altitudes of 2450 and 2070 masl, were occupied at the end of the Archaic period (Archaic IV sensu Cornejo et al., 1998), 
with datings of 3250 to $2980 \mathrm{cal} \mathrm{BP}$ (1250 to 980 BC) in Las Morrenas 1 and 3460-3340 BP (1460 to $1340 \mathrm{BC}$ ) in El Plomo (Cornejo et al., 1998; Planella et al., 2005; Planella et al., 2011; Planella et al., 2014a). These findings have enabled us to identify the presence of the first cultigens associated with hunter-gatherers in central Chile and to verify, through the large number of carbonized caryopses, the availability of Poaceae used by these groups in the high Andean ecosystem as well as woody resources such as Discaria chacaye (G. Don) Tortosa, which provides excellent prolonged combustion.

The proximity to the plant world of these hunter groups along their movement routes in search of animals (Camelidae and others) and raw materials for their tools, must necessarily have translated into a profound knowledge of plant life cycles, their virtues, their use for different purposes and in various aspects of daily life, and the content of any dangerous substances that lead to toxicity. The availability of a variety of species provided food resources that complemented the hunter groups' access to the meat of guanaco or other wild fauna. At the same time, conditions of a social, ritual or symbolic order may have stimulated knowledge and the incorporation and/or management of other species with greater nutritional value. This is the case for a variety of early handled quinoa (Chenopodium sp. aff. Chenopodium quinoa) (Planella et al., 2014a; Planella et al., 2014b; López et al., 2015). This evidence comes from sites located in the upper Maipo valley (Las Morrenas 1 and El Plomo), close to a mountain pass that would allow integration between the eastern and western slopes of the Andes within mobility circuits in which whole family groups might participate (Cornejo and Sanhueza, 2011) in the spring/summer thaw periods. Above an altitude of $2000 \mathrm{~m}$ in the Andes mountains, there are prolonged and abundant snowfalls and frosts from autumn to spring with subzero temperatures, hindering access from the valleys to these sites and over to the eastern slope. These conditions also limit the possibility of crop cultivation in this environment, where the natural vegetation is of the "Andean floor" type, with a predominance of long-lived woody or cushion plants (Gajardo, 1994). Nevertheless, it is important to note that the El Plomo site is located on a broad area of a high-Andean marsh (UTM 401000 N 6227000 E), offering favourable conditions for the preservation of organic material in a peat-like black sediment, where the findings were made. Included in this sediment, similar number of carbonized and dry specimens of Chenopodium sp. aff. Chenopodium quinoa were found, allowing us to consider the possibility of incipient attempts at cultivation (Planella et al., 2011), which is favored by the characteristics of the soil type. In the absence of ceramic pots, archaic hunters had to consume the fruits or other organs of Chenopodium after toasting them on hot stones, ashes or leather; the small size of the grains and low weight of a significant quantity of them would have made them easy to transport from place to place in bags made of leather or plant material, while the saponin content in the pericarp would have helped prevent rodent attacks in possible storage spaces (Planella et al., 2005). The carbonized fruits present diameters of up to $1.4 \mathrm{~mm}$ on both sites and have a perimeter strip with a truncated/ rounded edge. Unlike Las Morrenas 1, where all the fruits are carbonized $(\mathrm{n}=290)$, there are similar quantities of carbonized $(\mathrm{n}=110)$ and dried specimens ( $\mathrm{n}=99)$ in El Plomo. The dried fruits (Figure 1), which are exceptional in the region, present no radicles and are no larger than 0.8 to $1 \mathrm{~mm}$ in diameter (Planella et al., 2011). Under sweep electron microscopy (SEM), all these specimens present a marked prominence or "beak" on the embryo. This morphological feature, not previously noted in our studies, is discussed in Planella et al. (2011). The repeated appearance of a pronounced beak in this case must be treated with caution, as the seed pericarp is absent, which may affect the observation made (Bruno, 2006). On charred specimens of Chenopodium sp. aff. Ch. quinoa, the beak is difficult to distinguish, since in most of these specimens, the radicle has become detached from the rest of the seed or the 
end of the seed is swollen or protrudes, presumably due to carbonization.

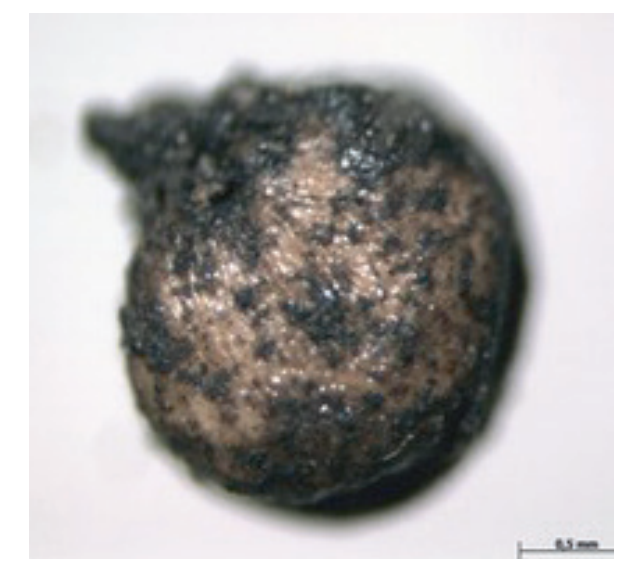

Figure 1. Specimen of dried Ch. quinoa seed from the El Plomo site.

In the central valley and coastal sites, among the Initial Ceramic-Using Communities (300 BC - 200 AD) the presence of Chenopodiaceae has also been revealed through archaeobotany in analyses of macro and microremains. Although few of these sites have been investigated, vestiges have been recorded in the Lenka Franulic site among residues (microfossils) adhering to a stone mortar; in the lower stratigraphic layer of the Lonquén site (85 \pm 200 BC, $105 \pm 200$ AD) (Sanhueza et al., 2003); in occupations associated with bedrock mortars (Los Valles stream, 150 to $60 \mathrm{BC}$ ) (Planella et al., 2017, 2018a); in human burials from Phase 1 of the El Mercurio site $(120 \pm 180 \mathrm{AD}, 150 \pm 150$ AD) (Falabella, 2000a); in the oldest levels of the La Granja site (110 to $550 \mathrm{cal}$. AD) (Planella and Tagle, 2004); and in somewhat later dates in the Estación Quinta Normal site (Belmar et al., 2010). Quinoa may have contributed to the achievement of a balanced nutrition by a population that was changing its eating habits. The mean $\delta 15 \mathrm{~N}$ value (4.5\%) obtained from seven individuals indicates a low consumption of meat, an important protein source for hunter-gatherers of the Archaic period. This more "vegetarian" diet in these communities may have been favored by the high protein contribution and diversity of high-quality essential amino acids found in quinoa as a foodstuff. The values for stable carbon isotopes (mean $\delta 13 \mathrm{Ccol}$ $-20.1 \%$ and 813 Cap $-12.2 \%$ ) are consistent with a diet based on $\mathrm{C} 3$ resources, which include quinoa and wild fruits (Falabella et al., 2007).

From ca. $200 \mathrm{AD}$, the so-called Bato groups are also present in central Chile. Their early dates overlap with those of the Initial Ceramic-Using Communities, with whom they share some cultural similarities (e.g., use of tembetá and lug handles), and their presence extends to the end of the Early Ceramic period (1200 AD). They continued their hunting and gathering activities and the lithic traditions of the Archaic period and a high mobility within their territories, both along the coast and in the inland valleys (Sanhueza et al., 2003). Quinoa is recorded in coastal sites from the south bank of the Aconcagua River, e.g., El Membrillar 2 and ENAP 3 (140 to 540 AD) (Belmar and Quiroz, 2009; Venegas et al., 2011) to the south bank of the Maipo River, at Las Brisas 3 (Rivas and González, 2008). The archaeobotanical records of the sites studied show that the diet of these groups was largely based on wild resources with seasonal variations in availability, while cultivated products formed just one more ingredient in the diet. Quinoa is without a doubt the most widespread of these products. Lagenaria sp. are represented in their pottery (Stehberg, 1976), and maize (Zea mays L.) appears for the first time, although it is still very scarce (Planella et al., 2014b; Planella and Falabella, 2015) and not of substantial importance in the diet. The isotope values obtained from Bato individuals, both from the coast and inland areas, suggest that consumption of this resource was still scarce and irregular. In coastal areas (9 individuals), considering that part of the food came from marine resources, the $\delta 13 \mathrm{Ccol}-18.0 \% \pm 1.0$ and $\delta 13 \mathrm{Cap}-10.9 \%$ \pm 1.5 values reflect the practically zero contribution of C4 plants (Falabella et al., 2007, 2008).

The Llolleo groups (400 AD to $1200 \mathrm{AD}$ ), partially contemporary with the Bato and interspersed in the same spaces in central Chile, present cultural 
characteristics that differ in various aspects (body ornaments, funerary practices, efficient lithic tool strategies) and in the forms and decorations used in their pottery, including anthropomorphic, zoomorphic and even phytomorphic modeled figures - in the latter case, these look like some species of gourd or Cucurbita sp. (Falabella and Sanhueza, 2005-2006). An important change that took place in these groups is that they clearly practiced horticulture. Archaeobotanical analyses have revealed the use of a set of cultigens, which included Zea mays L. (mazorca or marlo 3 to 5 $\mathrm{cm}$ long with eight rows of grains), Phaseolus sp., Lagenaria sp. and Cucurbita sp. as well as Chenopodium quinoa (Planella and Tagle, 2004); the latter is more ubiquitous than in the sites of the groups Bato mentioned above. The carbonization state of the archaeological quinoa grains does not allow us to assess whether the perisperm is translucent, as in the "sea level" ecotype (Tapia, 1979) or coastal quinoa (quinwa or dahue in the Mapuche language), which is still cultivated in the valleys of the Coastal Range in the O'Higgins and El Maule Regions south of Santiago, between $34^{\circ}$ and $40^{\circ} \mathrm{S}$. The perisperm of the quinoa cultivated in the Altiplano is opaque (Tagle and Planella, 2002). The maximum diameter of these grains is no more than 1.5 to $1.8 \mathrm{~mm}$ in records from different sites in central Chile (Belmar et al., 2010; Planella et al., 2014b) (Figure 2a).

The isotope signals in the individuals analyzed, from the coast and inland, confirm maize consumption (Falabella et al., 2008). Exploitation of this greater diversity, complemented by wild species and possibly the manipulation of Madia sp. and Poaceae, as suggested by the attributes of the macroremains of these taxa, enables us to recognize, first of all, that the use of pots for cooking made it possible to sufficiently cook leguminous plant products and other foodstuffs to facilitate digestion and avoid toxicity (Falabella and Planella, 1988-89), and second, that value was attached to the occupation of spaces with a larger water supply and to establishing more permanent settlement systems driven by the need to look after the sown crops and harvest the produce (Falabella et al., 2016). In this context, events for social congregation - and the use of pipes in smoking — assume a great importance (Falabella et al., 2001; Planella et al., 2018b). This practice had been started by the earlier communities mentioned, revealing the availability of Nicotiana sp. and other plants with psychoactive properties present in the region's ecosystems (Planella et al., 2012) and their important role in activities of ritual or other significance (Planella, 2005; Belmar et al., 2016; Planella et al., 2016).

In the so-called Aconcagua culture, established between the Aconcagua and Cachapoal rivers $\left(32^{\circ}\right.$ $20^{\prime}$ to $\left.34^{\circ} 50^{\prime} \mathrm{S}\right)$ in the Late Intermediate period (1000/1200 to 1450 AD), we find profound cultural and social changes manifested in different aspects of the Aconcagua groups customs, from the types of ceramic pots that they produced to the locations and mortuary particularities of their cemeteries, which were located away from dwelling

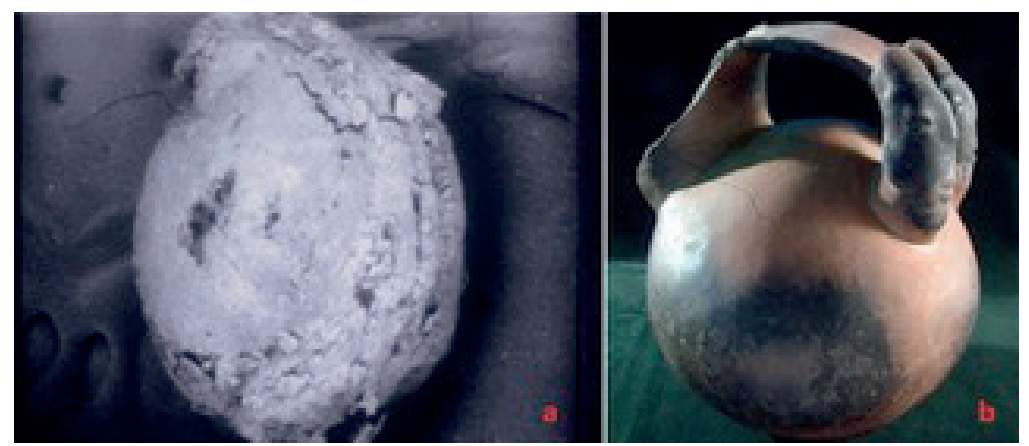

Figure 2. a) Carbonized Ch. quinoa seed from the La Granja site (diameter $1.8 \mathrm{~mm}$ ); and b) Llolleo jar with anthropomorphic modeled figures, central Chile. 


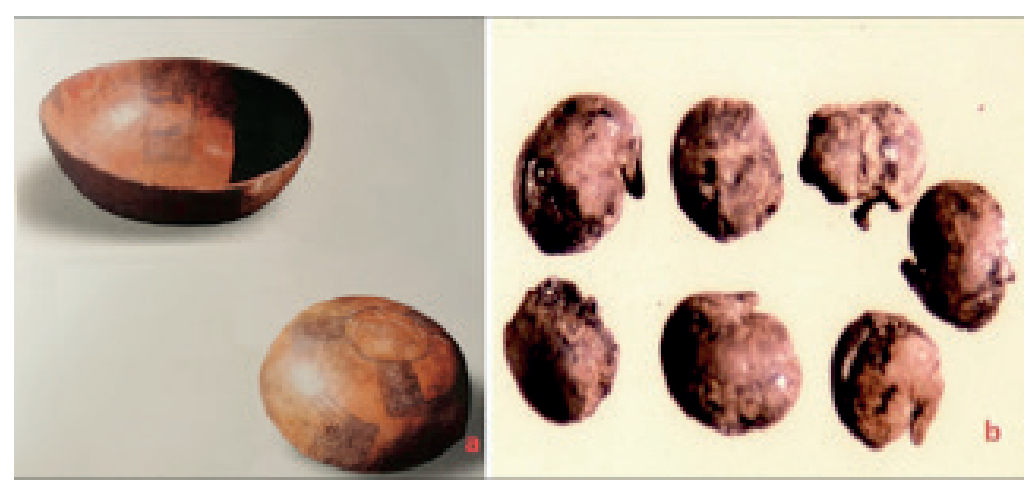

Figure 3. a) Dishes or pucos of the Aconcagua culture (Source: Pavlovic et al., 2003); and b) Ch. quinoa with a diameter of $2 \mathrm{~mm}$.

areas (Massone et al. 1998). It is of interest that in general, the Aconcagua groups continued to use many sites that had been occupied by previous populations, perhaps because of the strategic efficiency of these sites for increasing the scale of their horticultural activities. We also note some modifications in their diet, in the elements used in commensalism such as plates or dishes for handing around food, in the storage of the excess harvest in large jars such as at the Ruinas de Chada site (Planella and Stehberg, 1997), and in the differential characteristics presented by certain cultigens, specifically in maize and quinoa. The morphometric study of carbonized quinoa grains $(\mathrm{n}=88)$ from the Tejas Verdes 1 site, for example, which were recovered from an Aconcagua settlement at the mouth of the Maipo River, reflects an increase in size to $2 \mathrm{~mm}$ (Figure 3 ), contrasting with findings from the Archaic and Early Ceramic periods when quinoa grains in this region grew no larger than 1.5 to $1.8 \mathrm{~mm}$ in mean diameter (Planella, 2005). It may be that these people started to experiment with new management stages or degrees and/or to use other varieties of Ch. quinoa, which we also find in the case of maize (Planella et al., 2014) and Phaseolus sp. at the Las Pataguas site in Valdivia de Paine (Belmar and Quiroz, 2003) and Cueva Cerrillos in the precordillera of El Pangal (Falabella et al., 2010). Grinding stones or mortars show very large active surfaces to help with the trituration or processing of products, such as maize and quinoa, in larger quantities for consumption, either as flour or as beverage (chicha). Aconcagua jars also have a larger capacity (Falabella, 2000b). Stable isotope analysis confirms the increased consumption of $\mathrm{C} 4$ plants such as maize, and it is interesting to note that the mean carbon isotope values are found to be more positive in male individuals, suggesting that they in particular had a higher intake of chicha (Falabella et al., 2008). Quinoa is more ubiquitous in the sites of this period and is associated with maize, beans and wild flora, suggesting a fairly generalized consumption in the population.

Around 1440-1450 AD, the territories of central Chile started to be occupied and administered by foreign intruders, the Inkas, who brought with them the stamp of the Tawantinsuyu in a series of innovations from cultural, social and ritual aspects and in economic organization and architecture. Agricultural tasks and irrigation canals were reoriented and expanded using the local workforce (Stehberg, 1976), and the storage of produce was systematized in response to the new administration and feeding needs (Planella and Stehberg, 1997; Rossen et al., 2010). Archaeological investigations have shown the presence of quinoa in the residual contents of aríbalo jars and pucos (Belmar and Quiroz, 2007) and in different types of contexts: settlements, fortresses, kollcas or stores (Planella et al., 1993; Rossen et al., 2010) (Figure 4a), ritual sites (Pavlovic et al., 2012; Quiroz and Belmar, 2013), and tambos (Garceau et al., 2010). Introduced products were also found, such as ají (Capsicum sp.), some tubers (e.g., Helianthus sp.) and chuño (potato flour); 
these products form a sphere of syncretism in the diet of the population, which reflects the flexibility of the domination mechanisms exercised by the Inkas in frontier situations (Rossen et al., 2010). At the same time, Quechua linguistic terms were incorporated into the local ethno-taxonomic nomenclature, including plants and crops such as quinua, although in rural parts of the regions of central and southern Chile, the Mapuche word dahue or dawe is still used to this day (Mösbach, 1992; Planella et al., 2010), with modifications such as quinhua or quinwa in valleys and coastal locations (Tagle and Planella, 2002).

\section{Results}

Quinoa, apart from the high protein content of its grains, presents great adaptability to different environments and soil types and requires low investment in maintenance; these characteristics would have been advantageous from an early stage and during a long experimentation period as a diet option for groups characterized by high mobility for the purposes of hunting, gathering and searching for raw stone materials for tools and other artifacts. Given the available data, we propose that by the end of the Archaic period (3000 to $300 \mathrm{BC}$ ), these hunter-gatherers groups were among those who started the manipulation/ domestication of Chenopodiaceae in central Chile. The example of the central region suggests that this process was not inhibited by the gradual adoption of maize and other crops by pottery- users groups; these crops required greater access to water, seasonal rains, and a longer stay in the settlements by the incipient and later consolidated horticultural communities of the Early Ceramic period like Llolleo groups. The crops must be cared for and subsequently harvested and stored for consumption, retaining seeds for sowing to start the productive cycle afresh each year. In the Bato and Llolleo groups, we initially find a great dispersion of the dwelling sites, representing - with different degrees of formalization - this economic and social change (Sanhueza et al., 2007). The incorporation of a set of crop species, combined with the continued consumption of quinoa and terrestrial animals and marine fauna, adds up to an efficient nutritional balance that supported population growth. Moreover, the variability of everyday and/or ritual materials found for the Bato and Llolleo groups, and their modes of social organization indicate increasing levels of complexity, which is distinct from that of their predecessors of the Archaic period.

Among the Aconcagua groups, a new aspect of quinoa use appears: the attempt to obtain an improved phenotype with larger grains in the panicle, with some samples presenting mean grain diameters of $2 \mathrm{~mm}$. This progress is also reflected in the incorporation of new varieties of maize. Quinoa also becomes more ubiquitous, with larger quantities found in archaeological sites, reflecting its more constant, generalized use by the population. Nevertheless, its economic and social impact was smaller than that of maize,
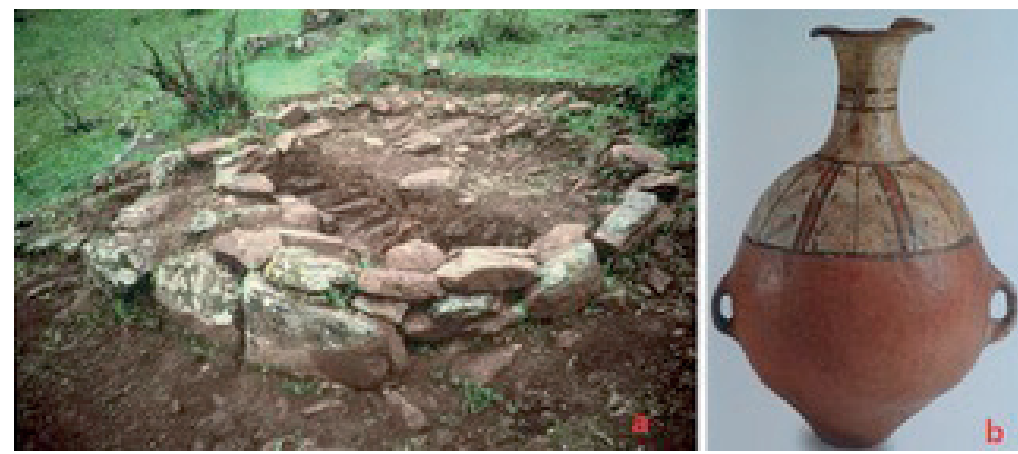

Figure 4. a) Kollca (storage system) of the Late period (Inka); and b) an aríbalo jar (Source: MCHAP 2009-2010). 
according to the isotope studies of human bones, since we find differentiated access to consumption of Zea mays between males and females. The diversity of food resources increases with the introduction of other species and products of plant origin brought to the region by the Inkas. This foreign invasion is a time of syncretisms in which both local and introduced products are used, reflecting flexible mechanisms in the process of territorial domination; it is also another step in the intensification of production and reflects the need to store produce in large jars or inside kollcas, in which the remains of quinoa are also clearly present.

\section{Conclusions}

From the earliest datings of the hunter-gatherer sites of the Archaic IV period (3000 to $300 \mathrm{BC}$ ) in central Chile in the high Andes section of the Maipo valley and of the Early Pottery sites in the central valley, coast and precordillera, Chenopodium sp. aff. Ch. quinoa presents the common feature of a grain size smaller than that of Altiplano quinoa. A majority of the pre-Hispanic records of the south-central region show the same findings, except for a few specimens recovered from sites ascribed to human occupations by later groups at El Vergel in southern Chile (Massone et al., 2007; Roa et al., 2015) and from Aconcagua group sites in central Chile (1000-1440 AD), where some diameters of $2 \mathrm{~mm}$ are recorded. A discussion of other attributes, such as surface color, presence of a translucent or opaque perisperm, type of ornamentation and thickness of the testa, and the presence of a radicle, is limited by the state of carbonization in which the specimens recovered from archaeological digs are generally found. One exception is the case of the grains found at the El Plomo site in the Andes of central Chile, which were preserved in a dried state that allowed the observation of their ivory color (thus excluding assignation to the black-seeded variety) and their truncated-rounded margin (which distinguishes them from the biconvex margin in wild species); however, the thickness of the seed testa could not be determined in the series analyzed. Despite these limitations, we propose with certainty that quinoa of irregular sizes, ranging between $1 \mathrm{~mm}$ and 1.5 to $1.8 \mathrm{~mm}$ in diameter (i.e., smaller than $2 \mathrm{~mm}$ ), was widely dispersed throughout the territory in question, along the sites occupied by pre-Hispanic inhabitants, prior to the introduction of new varieties or the probable local manipulation processes.

The archaeological and archaeobotanical data presented in this work were unknown when Wilson (1988) suggested that quinwa or dahue, considered the "sea level" ecotype (Tapia, 1979; Bertero, 2007) that still exists today in south-central Chile, constituted an archaic form of quinoa derived in earlier periods from ancestors that had been subjected to significant differentiation in the Andean highlands. This ecotype presents relictual attributes or archaic features associated with wild varieties, such as the glomerulate inflorescence of its panicles and the translucent perisperm of the fruits, which distinguish it from high Andean quinoa (Wilson, 1988) (Figure 5). Furthermore, it is particularly adapted to low altitudes between the sea level and 300 masl, and these characteristics, together with molecular studies of the germplasm, show that these sea level materials form a separate group from the high Andean specimens (Bertero, 2007). As mentioned above, the great antiquity of the availability of Chenopodiaceae/Amaranthaceae, their wide distribution in different ecosystems in central Chile, and their proven use among early hunter-gatherer groups and later horticultural communities, support the possibility of an independent local manipulation/ domestication process in south-central Chile. The substrate for this process was therefore an important plant resource in periods before maize was known and cultivated in this region and further south. More research is required in this area, in particular to obtain better results from DNA analyses of ancient specimens, which are to this date inadequate. 


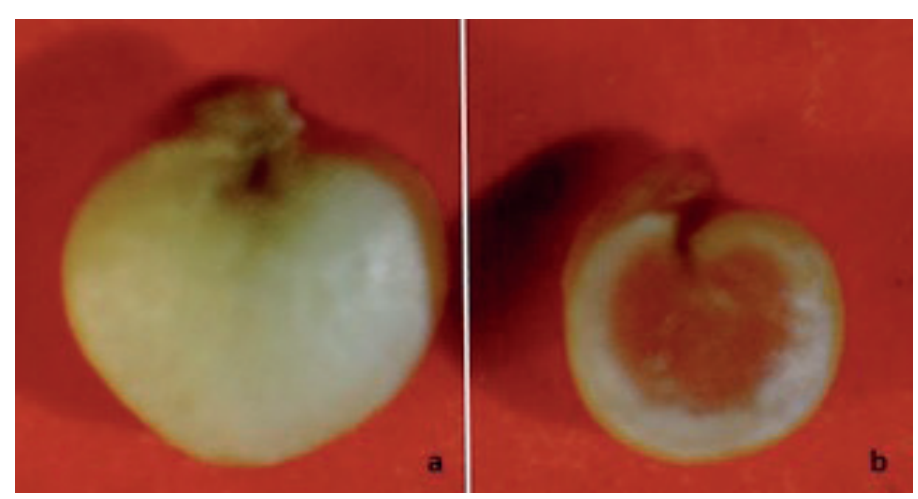

Figure 5. a). Altiplano quinoa with opaque perisperm; and b) "sea level" ecotype of quinoa with translucent perisperm.

The ubiquity of quinoa follows from its polysemous nature, since its presence forms a part of different use contexts, both in pre-Hispanic groups and contemporary communities. This ubiquity gives it added value, with wide variations in the economic, social and ritual significance that can be expressed by a society. Ethnographic studies in rural communities of northern and central Chile also attest to the continuity of its use and the variety of cultiva- tion and consumption systems that have been handed down over generations but are open to adopting changes that will guarantee its survival. This continuity is shown by the festive and ritual manifestations that accompany the sowing and harvesting of quinoa; these manifestations remain an important element in the religious/folk syncretism that varies by region and locality, particularly in the communities of northern, and central-south of Chile.

\section{Resumen}

M.T. Planella. 2019. La quinua en Chile central prehispánico: aportes de la arqueología y los procesos culturales. Cien. Inv. Agr. 46(2): 69-81. Este artículo proporciona datos arqueológicos, arqueobotánicos, etnográficos y morfométricos relacionados a la presencia de Chenopodium y el uso de quinua en Chile central desde fechas anteriores a la era Cristiana hasta el presente, y discute la importancia de este cultígeno en el desarrollo económico y social de los distintos grupos culturales pre-Hispanos que habitaron las diferentes áreas y ecosistemas de la región. Estos antecedentes permiten acceder a los inicios y desarrollo de una larga historia de la quinua acompañando a los pueblos originarios, sus descendientes y grupos resultantes del mestizaje Hispano-indígena y que su cultivo, consumo y participación en prácticas sociales de distinta connotación, continúan vigentes en distintas comunidades rurales del Chile actual.

Palabras clave: Chile central, grupos culturales, quinua. 


\section{References}

Belmar, C., and L. Quiroz. 2003. Informe análisis carpológico. Sitio Las Pataguas, Valdivia de Paine. Report Proyecto de rescate arqueológico del sitio Las Pataguas. Responsible Researcher: Katherine Westfall.

Belmar, C., and L. Quiroz. 2007. Análisis arqueobotánico sitio Estación Intermodal Quinta Normal, microfósiles recuperados de los fragmentos cerámicos y ceramios. Second stage report Proyecto Extensión Línea 5 de Metro.

Belmar, C., and L. Quiroz. 2009. Informe Preliminar Análisis carpológico: Sitio ENAP 3, Concón, V Región. Report for ENAP.

Belmar, C., L. Quiroz, and V. Reyes. 2010. Las Comunidades Alfareras de la Zona Central son solamente cazadoras-recolectoras: una pregunta enunciada desde el registro carpológico del sitio Estación Quinta Normal, Línea 5 del Metro de Santiago. In: Actas del XVII Congreso Nacional de Arqueología Chilena, Tomo II. Sociedad Chilena de Arqueología, Santiago. p. 1179-1190.

Belmar, C., X. Albornoz, S. Alfaro, F. Meneses, C. Carrasco, L. Quiroz, M.P. Babot, and M.T. Planella. 2016 Reconstruyendo las prácticas fumatorias del sitio La Granja (130 a 1000 D.C, valle del rio Cachapoal, VI Región, Chile central) a partir de los microfósiles. Chungara, 48(1):53-72.

Bertero, H.D. 2007. Quinoas de 'nivel de mar', ¿resultado de una domesticación independiente? In: CIHDE editors, Libro de Resúmenes, Congreso Internacional de la Quinua. Universidad Arturo Prat, Iquique. p. 27.

Bruno, M.C.W2006. A Morphological Approach to Documenting the Domestication of Chenopodium in the Andes. In: D. Bradley, M.A. Zeder, E. Emshwiller, and B.D. Smith, editors, Documenting domestication: New Genetic and Archaeological Paradigms. University of California Press, Berkeley. p. 32-45.

Coil, J., A. Korstanje, S. Archer, and C. Harstof. 2003. Laboratory goals and considerations for multiple microfossil extraction in archaeology. Journal of Archaeological Science 30: 991-1008.
Cornejo, L., M. Saavedra, and H. Vera. 1998. Periodificación del Arcaico en Chile central: una propuesta. Boletín de la Sociedad Chilena de Arqueología 25:36-39.

Cornejo, L., and L. Sanhueza. 2011. Caminos que cruzan la Cordillera: el rol del paso del Maipo en la ocupación de la Cordillera en Chile central. Revista Chilena de Antropología 23:101-22.

Falabella, F. 2000a. El Sitio Arqueológico de El Mercurio en el contexto de la problemática cultural del período Alfarero Temprano en Chile central. In: Actas del Segundo Taller de Arqueología de Chile Central. http:// www.arqueologia.cl/Actas2/Falabella.Pdf, (accessed 2 July 2015).

Falabella, F. 2000b. El estudio de la cerámica Aconcagua en Chile central: una evaluación metodológica. Contribución Arqueológica 5:427-458

Falabella, F., and M.T. Planella. 1988-89. Alfarería temprana en Chile central: Un modelo de interpretación. Paleoetnologica 5:41-64.

Falabella, F., and L. Sanhueza. 2005-06. Interpretaciones sobre la organización social de los grupos alfareros tempranos de Chile central: Alcances y perspectivas. Revista Chilena de Antropología 18:105-133.

Falabella, F., M.T. Planella, and B. Tagle. 2001. Pipe e tradizione di fumare nelle societa preispaniche del Periodo Agroceramico Precoce nella regione centrale del Cile. Eleusis. Nuova Serie 5:137-152.

Falabella, F., M.T. Planella, E. Aspillaga, L. Sanhueza, and R.H. Tykot. 2007. Dieta en sociedades alfareras de Chile central: Aporte de análisis de isótopos estables. Chungara 39(1):5-27.

Falabella, F., M.T. Planella, and R.H. Tykot. 2008. El maíz (Zea Mays) en el mundo prehispánico de Chile central. Latin American Antiquity 19(1):25-46.

Falabella, F., L. Cornejo, I. Correa, E. Latorre, M. Vásquez, and L. Sanhueza. 2010. Los «escondrijos» en reparos rocosos de la zona de El Pangal y sus componentes culturales, In: Actas XVII Congreso Nacional de Arqueología Chilena, Tomo II. Sociedad Chilena de Arqueología, Santiago. p. 719-27. 
Falabella, F., D. Pavlovic, M.T. Planella, and L. Sanhueza. 2016. Diversidad y heterogeneidad cultural y social en Chile Central durante los periodos Alfarero Temprano e Intermedio Tardío (300 años a.C. a 1.450 años d.C.). In: F. Falabella, M. Uribe, L. Sanhueza, C. Aldunate, and J. Hidalgo, editors, Prehistoria en Chile. Desde sus primeros habitantes hasta los Incas. Editorial Universitaria, Santiago. p. 365-399.

Gajardo, R. 1994. La vegetación Natural de Chile. Clasificación y distribución Geográfica. Editorial Universitaria, Santiago.

Garceau, CH., V. MCRostie, R. Labarca, F. Rivera, and R. Stehberg. 2010. Investigación arqueológica en el sitio tambo Ojos de Agua, Cordillera del Aconcagua. In: Actas XVII Congreso Nacional de Arqueología Chilena, Tomo I. Dirección de Museología, Universidad Austral, Valdivia. p. 351-361.

Heusser, C.J. 1983. Quaternary Pollen Record from Laguna de Tagua-Tagua. Chile. Science 219:1429-1432.

Heusser, C.J. 1990. Ice Age vegetation and climate of subtropical Chile. Paleogeography, Paleoclimatology, Paleoecology 80(2):107-127.

Jackson, D., C. Méndez, R. Seguel, A. Maldonado, and G. Vargas. 2007. Initial occupation of the Pacific Coast of Chile during Late Pleistocene Times. Current Anthropology 48(5):725-731.

López, M.L., M.C. Bruno, and M.T. Planella. 2015. «El género Chenopodium: metodología aplicada a la identificación taxonómica en ejemplares arqueológicos. Presentación de casos de estudio de la región surandina». In: C. Belmar, and V. Lema, editors, Avances y desafíos metodológicos en Arqueo-botánica. Miradas consensuadas y diálogos compartidos desde Suramérica. Universidad SEK, Santiago. p. 89-121.

Maldonado, A., and C. Villagrán. 2002. Paleoenvironmental changes in the semiarid coast of Chile $\left(32^{\circ} \mathrm{S}\right)$ during the last $6200 \mathrm{cal}$. years inferred from a swamp-forest pollen record. Quaternary Research, 58(2):130-138.

Maldonado, A., and C. Villagrán. 2006. Climate variability over the last 9,900 cal. years BP from a swamp pollen record along the semiarid coast of Chile. Quaternary Research 66:246-258.

Maldonado, A. 2007. Nuevos antecedentes para la comprensión del paleoambiente Holocénico de la zona de Los Vilos y su relación con las ocupaciones humanas. Final Report FONDECYT 1030585, Evaluación crítica del poblamiento inicial del semiárido de Chile: procesos de exploración y adaptación ambiental.

Maldonado, A. 2010. Early Holocene climate change and human occupation along the semiarid coast of north-central Chile. Journal of Quaternary Science 25(6):985-988.

Massone, M., E. Durán, R. Sánchez, F. Falabella, F. Constantinescu, N. Hermosilla, and R. Stehberg. 1998. Taller de Cultura Aconcagua: evaluación y perspectivas. Boletín de la Sociedad Chilena de Arqueología 25:24-30.

Massone, M., C. Silva, and R. Labarca. 2007. La sociedad El Vergel y el manejo de los recursos vegetales en la isla Santa María entre los siglos X y XVI d.C. Fondo de Apoyo a la Investigación patrimonial, Centro de Investigaciones Diego Barros Arana Reports.

Mösbach, E.W. 1992. Botánica Indígena de Chile. Editorial Andrés Bello.

Museo Chileno de Arte Precolombino. 2009-2010. Chile bajo el Imperio de los Inkas. MCHAP, Santiago. p.103.

Núñez, L., J. Varela, R. Casamiquela, V. Schiappacasse, H. Niemeyer, and C. Villagrán. 1994. Cuenca de TaguaTagua en Chile: El ambiente del Pleistoceno y ocupaciones humanas. Revista Chilena de Historia Natural 67(4):503-519.

Pavlovic, D., R. Sánchez, and A. Troncoso. 2003. Prehistoria del Aconcagua. Colección Cuadernos Patrimoniales. Ediciones del Centro Almendral Corporación CIEM, Aconcagua.

Pavlovic, D., A. Troncoso, R. Sánchez, and D. Pascual. 2012. Un tigre en el valle. Vialidad, arquitectura y ritualidad incaica en la cuenca superior del río Aconcagua. Chungara 44(4):551-569.

Planella, M.T., R. Stehberg, B. Tagle, H. Niemeyer, and C. Del Río. 1993. La fortaleza indígena del Cerro Grande de La Compañía (Valle del Cachapoal) y su relación con el proceso expansivo meridional 
incaico. In: Actas del XII Congreso Nacional de Arqueología Chilena, Tomo II. Sociedad Chilena de Arqueología, Santiago. p. 403-421.

Planella, M.T., and R. Stehberg. 1997. Intervención Inka en un territorio de la cultura local Aconcagua de la zona centro-sur de Chile. Tawantinsuyu 3:58-78.

Planella, M.T., and B. Tagle. 2004. Inicios de presencia de cultígenos en la zona central de Chile, períodos Arcaico y Agroalfarero Temprano. Chungara 36 (spec.num.1):387-399.

Planella, M.T. 2005. Cultígenos prehispanos en contextos Llolleo y Aconcagua en el área de desembocadura del río Maipo. Boletín Sociedad Chilena de Arqueología 38:9-23

Planella, M.T., L. Cornejo, and B. Tagle. 2005. Alero Las Morrenas 1: Evidencias de cultígenos entre cazadores recolectores de finales del período Arcaico en Chile central. Chungara 37(1):59-74.

Planella, M.T., and V. McRostie. 2008. Manejo de la información arqueobotánica y desafíos teóricos: una mirada propositiva desde el sitio paleoindio Santa Julia, Los Vilos (31029'S) Chile. In: S. Archila, M. Giovannetti, and V. Lema, editors, Arqueobotánica y Teoría Arqueológica. Discusiones desde Suramérica. Uniandes-Ceso, Colombia. p.30-249.

Planella, M.T., V. MCRostie, and F. Falabella. 2010. El aporte arqueobotánico al conocimiento de los recursos vegetales en la población alfarera temprana del sitio El Mercurio. In: Actas XVII Congreso Nacional de Arqueología Chilena, Tomo II Sociedad Chilena de Arqueología, Santiago. p. 1255-1265.

Planella, M.T., R. Scherson, and V. MCRostie. 2011. Sitio El Plomo y nuevos registros de cultígenos iniciales en cazadores del Arcaico IV en Alto Maipo, Chile central. Chungara 43(2):189-202.

Planella, M.T., M. L. López, and M.C. Bruno. 2014a. Capítulo No 1.3 La domesticación y distribución Prehistórica. In: D. Bazile, D. Bertero, and C. Nieto, editors, Estado del Arte de la quinua en el Mundo en 2013. FAO (Santiago, Chile) and CIRAd (Montpellier, France). p. 33-48.

Planella, M.T., F. Falabella, C. Belmar, and L. Quiróz. 2014b. Huertos, chacras y sementeras. Plantas cultivadas y su participación en los desarrollos culturales de Chile central. Revista Española de Antropología Americana 44(2):495-522.

Planella, M.T., and F. Falabella. 2015. El maíz (Zea mays L.) prehispánico en Chile Central. In: C. Belmar, and V. Lema, editors, Avances y desafíos metodológicos en arqueobotánica. Miradas consensuadas y diálogos compartidos desde Sudamérica. Universidad SEK, Santiago. p.143-156.

Planella, M.T., C. Belmar, L. Quiróz, F. Falabella, S. Alfaro, J. Echeverría, and H. Niemeyer. 2016. Towards the Reconstrucction of the Ritual Expressions of Societies of the Early Ceramic Period in Central Chile: Social and Cultural Contexts associated with the Use of Smoking Pipes. In: E.A. Bollwerk, and S. Tushingham, editors, Perspectives on the Archaeology of Pipes, Tobacco and other Smoke Plants in the Ancient Americas. Springer International Publishing, Switzerland. p.231-254.

Planella, M.T., G. Santander, and V. MCRostie. 2017. Aportes a la discusión sobre piedras tacitas en Chile Central. Intersecciones en Antropología 18:5-17.

Planella, M.T., G. Santander, and V. MCRostie. 2018a. Estudio morfo-tecnológico y análisis de microfósiles en piedras tacitas de Chile central. In: S. Rojas-Mora and C. Belmar editors, De las muchas historias entre las plantas y la gente. Alcances y perspectivas de los estudios arqueobotánicos en América Latina. Instituto Colombiano de Antropología e Historia, Bogotá. p. 261-295.

Planella, M.T., C. Belmar, L. Quiróz, H. Niemeyer, F. Falabella, S. Alfaro, J. Echeverría, X. Albornoz, C. Carrasco, and K. Collao-Alvarado. 2018b. Saberes compartidos y particularidades regionales en las prácticas fumatorias de sociedades del período Alfarero Temprano del norte semiárido, centro y sur de Chile, América del Sur. Revista Chilena de Antropología 37:20-57

Quiróz, L., and C. Belmar. 2013. El rol de las plantas en el entendimiento de las estrategias de dominación Incaica en el sitio Cerro La Cruz (V Región, Chile). In: S. Rojas-Mora and C. Belmar editors, De las muchas historias entre las plantas y la gente. Alcances y perspectivas de los estudios arqueobotánicos en América Latina. In- 
stituto Colombiano de Antropología e Historia, Bogotá. p. 55-73.

Rivas, P., and J. González. 2008. Las Brisas-3, sitio Agroalfarero Temprano en Santo Domingo. V Región, Chile. Clava 7:27-49.

Roa, C., C. Silva, and R. Campbell. 2015. Dos asentamientos en la Mocha y el uso de recursos vegetales (1000-1700 d.C.). Actas del XIX Congreso Nacional de Arqueología Chilena, Arica (oct. 2012). p.549-559.

Rojas, G. 1991. Posibilidades de alimentación vegetal del Hombre de Cuchipuy. Revista Chilena de Antropología 10:25-35.

Rossen, J., M.T. Planella, and R. Stehberg. 2010. Archaeobotany of Cerro del Inga, Chile, at the Southern Inka Frontier. In: M.A. Malpass and S. Alconini, editors, Distant Provinces in the Inka Empire. University of Iowa Press, Iowa. p.15-43.

Sanhueza, L., M. Vásquez, and F. Falabella. 2003. Las sociedades Alfareras Tempranas de la cuenca de Santiago. Chungara, 35(1):23-50.

Sanhueza, L., L. Cornejo, and F. Falabella. 2007. Patrones de asentamiento en el período alfarero temprano de Chile central. Chungara, 39(1):103-115.

Stehberg, R. 1976. La Fortaleza de Chena y su relación con la ocupación incaica de Chile Central. Publicación Ocasional del Museo Nacional de Historia Natural 23:3-37.

Tagle, B., and M.T. Planella. 2002. La quinoa en la zona central de Chile. Supervivencia de una tradición prehispana. Editorial IKU. Santiago.
Tapia, M. 1979. Historia y Distribución geográfica. In: M. Tapia, H. Gandarillas, S. Alandia, A. Cardozo, A. Mujica, R. Ortiz, V. Otazu, J. Rea, B. Salas and E. Zanabria, editors, La Quinoa y Kañiwa. Cultivos andinos. Instituto Interamericano de Ciencias Agrícolas (IICA) - Centro Internacional de Investigaciones para el Desarrollo (CIID), Bogotá. p. 11-19.

Valero- Garcés, B.L., B. Yeny, M. Rondanell, A. Delgado-Huertas, S.J. Burns, and H. Veit. 2005. Paleohydrology of Laguna de Tagua-Tagua (34 30 'S) and moisture fluctuations in central Chile for the last $40.000 \mathrm{yr}$. Journal of Quaternary Science Vol. 20:625-641.

Venegas, F., H. Avalos, and A. Saunier. 2011. Arqueología e historia del curso medio e inferior del río Aconcagua. Ediciones Universitarias de Valparaíso.

Villagrán, C., and J. Varela. 1990. Palynological evidence for increased aridity on the central Chilean coast during the Holocene. Quaternary Research 34:198-207.

Villa-Martínez, R., C. Villagrán, and B. Jenny. 2003. The Last 7500 cal. yr. B.P. of Westerly Rainfall in Central Chile Inferred from a High-Resolution Pollen Record from Laguna Aculeo ( $\left.34^{\circ} \mathrm{S}\right)$. Quaternary Research 60:284-293.

Wilson, H.D. 1988. Quinua biosystematics I: Domesticated populations. Economic Botany 42(4):461-77. 